\title{
Fonó és Kisgyalán községek gazdasági épületeiben alkalmazott tartástechnológiai eljárások változása a 20 . század második felében
}

\author{
LANSZKINÉ SZÉLES GABRIELLA
}

Kaposvári Egyetem, Természetvédelmi és Környezetgazdálkodási Tanszék H-7400 Kaposvár, Guba Sándor út 40., e-mail: lanszkine.gabriella@ke.hu

\begin{abstract}
LANSZKINÉ, Sz. G.: Changes in breeding technology of agricultural buildings in Fonó and Kisgyalán during the 20th century. Abstract: The aim of this study was to compare agricultural buildings and their economic role in two neighbouring villages of Outer-Somogy; Fonó and Kisgyalán. I analyzed how the function of these buildings altered within the branches of animal husbandry, during joint management and after the change of regime. Breeding technology employed in barns, feed storage strategies in sheds, corn-cribs and attics were also described based on reminiscences. The changes in economic conditions facilitated building economic-necessity structures in some cases. In addition, the effects of changing attitude of peasants due to lifestyle modification were also highlighted based on examples such as sleeping in the barn.
\end{abstract}

Keywords: breeding technology, feed storage, corn-cribs, building economic-necessity, Somogy county

\section{Bevezetés}

Két Külső-Somogyban található szomszédos község Fonó és Kisgyalán gazdasági épületeinek, népi építészeti szempontból - főként az istállók külcsínét tekintve - történt számbavételét tekintettem elsőként feladatomnak. Jelen tanulmányban ezen épületek szarvasmarha-tenyésztésben betöltött szerepét vizsgáltam 1945 előtt, és a közös gazdálkodás idején. Valamint érdekelt, hogy alakult a többi állattenyésztési ágban a rendszerváltás után a gazdasági épületek sorsa. Az istállókban alkalmazott tartástechnológia, a pajtákban, górékban, a padlásokon történő takarmány tárolás módszereinek megismerése fontos a múlt megismeréséhez.

A gazdák 1920-30-as években született gyerekeinek szíves közlései nyomán, képet alkothatunk a két falu életéröl, arról hogy követték tovább, amíg lehetett azt az életmódot, amin szüleik, nagyszüleik elindultak. Ami az elért eredmények mögött volt, az megkövetelte mind az elöre gondolkodást, kalkulálást, szellemi, anyagi tőkét egyaránt, mind a fizikai erőfeszítést, a munkavégző képesség maximális kihasználását. „Nem kímé'te (kímélte) magát a paraszt” ez a sokszor, sokak szájából elhangzott mondat is sejteti az eredményeket. A saját maga illetve családja számára dolgozó paraszt, többre törekvési vágya folytán, inkább megvonta a szájától a falatot, de állatai számára igyekezett a legjobbat nyújtani, mind takarmányozás, mind tartástechnológia terén. Aminek aztán meg is lett a gyümölcsöző eredménye. A Fonóban számba vett különösen tetszetős 25 db istállós pajta időtállónak bizonyult, a kor igényeit messze kielégítette.

\section{Anyag és Módszer}

A tanulmány két részre való bontása után, az anyag és módszert a Fonó és Kisgyalán községek népi építészete, az istállók rendeltetésének változása (LANSZKINÉ és LANSZKI 2014), tartalmazza ami a jelen kötetben szereplö közlemény.

\section{Eredmény és értékelés}

\section{Az alkalmazott tartástechnológiai eljárások}

A legtöbb helyen a vasbetongerendás tetőszerkezet (1-2. ábra), akár 4 m-es istálló belmagasság, a kellő fény bebocsátására alkalmas ablakok, a tágas tér, a hosszú állások, a tartás technológiai feltételek optimális meglétét igazolja (3. ábra).

A hosszú állásokat és az ehhez tartozó jászol magasságát szintén sok éves tapasztalattal, illetőleg a generációkon át hagyományozódott tudással építette meg a közbirtokosság, természetesen a kőműves szakértelmével együtt.

„A bejárattal szemközt mindig balkéz felöl a marhák állnak, az ajtó felül, a tehenekkel, növendékekkel, bikákkal, szemben, a borgyuk (borjak) vannak." A szarvasmarha jászlakban találhatóak a betonba rögzített vaskarikák, amik a helyek számát határozzák meg, ahová a marha kötéllel, vagy bika lánccal kötötték az állatokat. Jobbról a lovak jászla helyezkedik el magasabban, mint a szarvasmarha jászlak. Esetenként válaszfal található a lovak és a marhák között. $A z$ etetőrács több helyütt leszerelésre került, amiből a szálastakarmányt kapta a ló. Az etetőrács megnevezésére gyakran a „srágla” szó a használatos (4. ábra).

Azonban a jászlak egytöl egyig a helyükön vannak, a leszármazott tulajdonosoknál. A jászlak pontosan be vannak tervezve a helyükre, a 25 db gazdasági épületegyüttest képviselő istállókba. A szerényebb istállókba, az elöre gyártott, könnyen mobilizálható jászlakat építették be. A beton jászol megvásárlása is anyagi áldozatot követelt, - ezért a gondos gazda szép cirkalmazott fekete betükkel, ráírta a nevét, és címét a betonjászol oldalára hirdetve a tulajdonjogot, később pedig azt, hogy ki fejezte be elöbb a szarvasmarhatenyésztést. Ugyanis ha más udvarába került a jászol, az új tulajdonos nem tüntette el a régi tulajdonos, esetleg komája, sógora nevét a jászolról.

A tenyész - és a hízó állatok mögött - ahol a billenős ablakok és a hármas ajtók is találhatóak - helyez- 
ték el a szopós borjakat, valamint az ágyat a kint alvó családtag számára. Legtöbb helyen téglából készített úgynevezett „borjú választék” található, ha ez ajtóval ellátott, akkor zárt kötetlen tartásról van szó (5. ábra).

Ha nyitott a borjú számára biztosított hely, kötött tartásról, beszélhetünk. Amikor a borjú nem került eladásra a választás után, átkerült a vele szemközti oldalra. Így minden korcsoportnak megvolt a maga helye.

$A z$ állategészségügyi szempontokat is szigorúak vették. A falak tisztán tartása érdekében évente tavasszal meszeltek, 1,5 m magasságig sötétre, általában feketére, vagy szürkére színezték a falat az úgynevezett „feketeporral”. Amíg tartott a meszelés, arra az időre sem kötötték ki az állatokat az istállóból. Ez a munkafolyamat minden esetben női munka volt.

A ló, szarvasmarha ápolása vakaróval történt, napi rendszerességgel. „Ezekben, az istállókban kizárt dolog, hogy előfordult volna, olyan állat, - amely nem saját tulajdonú állat esetén gyakran - hogy a trágyába belefeküdt marháról pikkelyszerüen lóg a vastagon rárakódott trágya." Az állatok gazdájuk gondoskodása révén, azontúl, hogy egészségük érdekében történik a vakarás, teljesen kezessé válnak, ami nem utolsó szempont, egy kiállításra szánt üsző, bika, tehén esetében. Gazdaasszonyuk, a család nagylányai hangját ismerték az állatok, így „együtt müködtek”, ha szépen kérlelöleg szóltak hozzájuk. Szótfogadtak ha mögéjük, föléjük kellett, a meszelővel nyúlni, abba az irányba léptek odébb amerre kellett. Ablaktisztítás, szellőztetés is a rend részét képezte.

Etetéskor, itatáskor, szintén az állatok közé kellett menni. Etetés előtt minden esetben „kitürülték” a jászlat, hogy az esetlegesen bent maradt széna törmelék, abrak, répamaradvány erjedésnek ne induljon, ne okozzon hasmenést. Jászol takarításkor különösképpen kellet vigyázni föként fiatal üszőknél hogyha „folat" (ivarzik), ekkor ugyanis felugrált társaira, vagy arra, aki előtte állt.

Az abrakolást az végezte, aki éppen otthon volt, az 1950-es évek végétől aszerint, hogy a családból, kinek hogy volt beosztva a munkaideje a termelőszövetkezetben.

„Tekintettel arra hogy a háztáji gazdaságok (majd a kisegítő és egyéb kisgazdaságok) termékeire az országnak nagy szüksége volt, a politika nemcsak eltürte, de támogatta is tevékenységüket. Az önellátás mellett teret kapott az árutermelés, amelynek bevétele a termelés bővítését kevésbé, de a saját környezet felújítását, korszerüsítését (...) az egyéb jövedelmek bevonásával és takarékossággal lehetővé tette. Erre azért is szükség volt, mert az állam a falusi infrastruktúra kiépítéséből, lakásépítés terheiből kisebb terhet vállalt, mint a városok és lakói esetében. A háztáji (kisegítő) gazdaságból származó jövedelem alapja az emberi munka. A kistermelésre fordított idő gazdaságonként, napi 4,9 óra (országos) illetve 5,3 óra (Somogy megye). (Ez az év valamennyi napjára vonatkozik!) A nők naponta átlagosan egy órával többet dolgoztak, mint a férfiak, munkával eltöltött átlagos idejük 10,5 óra, a férfiaké 9,5 óra." ${ }^{1}$ Ez a megállapítás Fonóban, Kisgyalánban szintúgy tapasztalható volt.

A feleség végezte az itatást, majd a férj „darázott” (abrak kiosztása). Mikor a férj, megjött a termelőszövetkezetből az ott elvégzett reggeli munkája után, a feleség akkor indult szintén a termelöszövetkezetbe munkába. Természetesen a férj is visszament még aznap a termelöszövetkezetbe dolgozni. Így osztották be a családtagok egymás közt a „háztájiba”, (akkorra már ezt a megnevezést kapta), és a „közösben” végzett munkát.

„Az itatás, ha például 7 bika volt az istállóban, a következőképpen történt, 6 ivott egyszerre, az eléjük lehelyezett vödörböl. 4 bika állt balról az állásokba, 1 a lovak helyén, 2 pedig a borjuk helyén, ezek voltak a fiatalabbak. Nem egyidősek voltak, származhattak saját borgyazásból (ellésből), vagy vásárban vásároltak is lehettek. Ebből következőleg az is elöfordult, hogy sehogy sem tudtak összeszokni, volt olyan bika társaság, hogy két bika állandóan verekedett, mindkettőnek vérbe forogtak a szemei állandóan."2

Itatáskor, először megtörtént a vödrök tele húzása vízzel, ami szintén időigényesebb folyamat, mint a csapot kinyitni. A vödör leengedése szakértelemmel bíró személy esetén gyors, tenyérrel a kút hengerét irányítva könnyedén gyorsan lefuttatja a kötelet vagy a hengeren lévő láncot, végül a vödör vízbe csobban. Aki tapasztalatlan, a kút hajtókarjának segítségével, sokkal lassabban teszi ezt meg. „Miután mind a 7 vödörbe víz került, körü' vó't a kút rakva vödörrel. Ésszerü okból a legtöbb helyen a kút az istállóval szemben volt. $A$ víz behordása után, elejbük letettem a vödröt, egyszerre kapott 6, felügyeltem rájuk, míg ittak, abban a sorrendben került eléjük a vödör, ahogy megszokták. A 7-ik utóbb kapott, ami a lovak helyén volt. 5 bika fejenként 10 I vizet ivott meg egyszerre, a két kisebb fél-fél vödörrel ivott. Naponta kétszer volt itatás." A tehén a jó tejelés érdekében, minél többet kellett, hogy igyon, ,volt, hogy a 4-ik vödörböl is ivott.” ${ }^{3}$

Volt, hogy az elszabadult bika, akihez hozzá volt szokva annak hagyta magát megkötni. Bár nem egykönnyen, oda-odament a helyére gazdaasszonyához, tartotta a nyakát, de mire rákerült volna a kötél, úgy döntött, hogy inkább a szabadság. Ismerve az állat viselkedési szokásait, segítségért kellet folyamodni. A fiatalasszony megkérte anyósát, őtőle mégsem kívánhatta, hogy a bika elé álljon, hogy menjen ki az utcára, és akárki férfi jön, szóljon neki, hogy jöjjön be segíteni. A segítség meg is érkezett és annyi volt a dolga, hogy „vellával” (villával) helyre irányítsa a szabadságát élvezni akaró egyedet. Amit aztán ekképp kommentált az utcáról beszólított, jártába-keltébe, a termelőszövetkezetben dolgozó férj számára: „Elemér kérem szépen otthon borzalmas életveszélyes dolog van. Kérem szépen!"

Király I. Sz. 2006: 140.

2 Pál Elemérné (Zóka Margit 1931) Fonó Petőfi u. 50. szíves közlése.

3 Pál Elemérné 


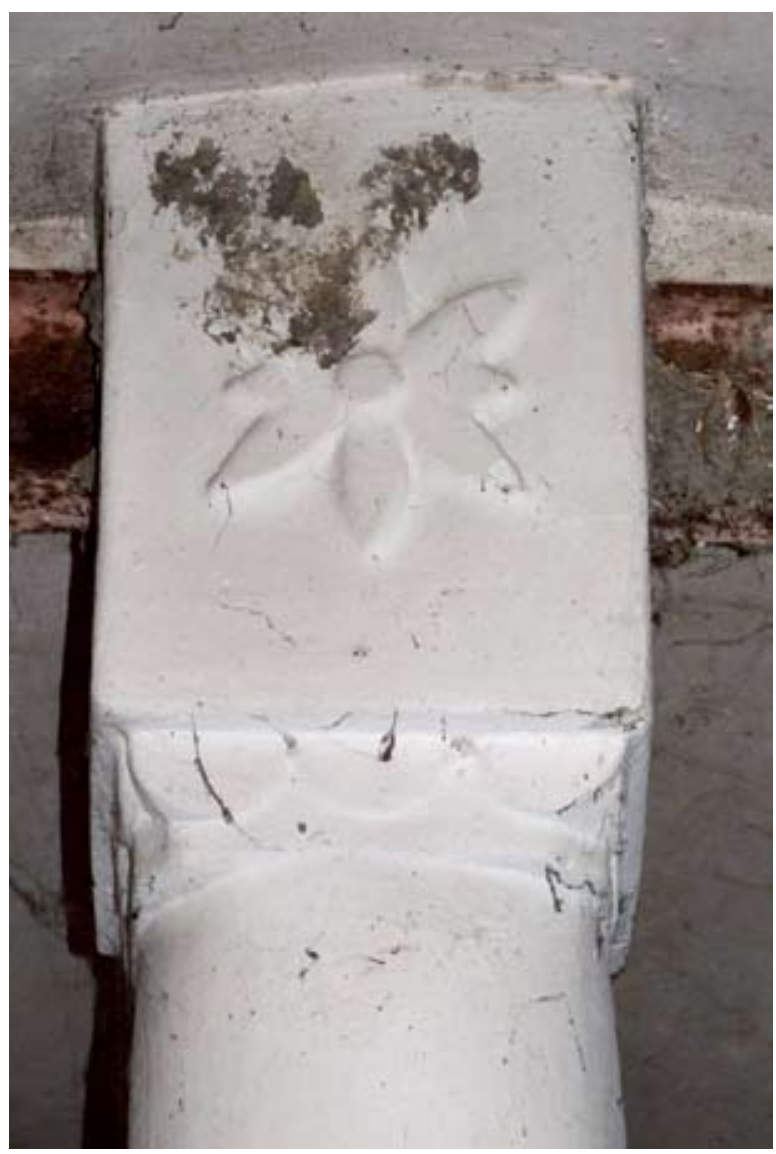

1. ábra: Tartó oszlop (Fonó, Petőfi utca)

Figure 1: Supporting-pillar (Fonó, Petőfi Street)

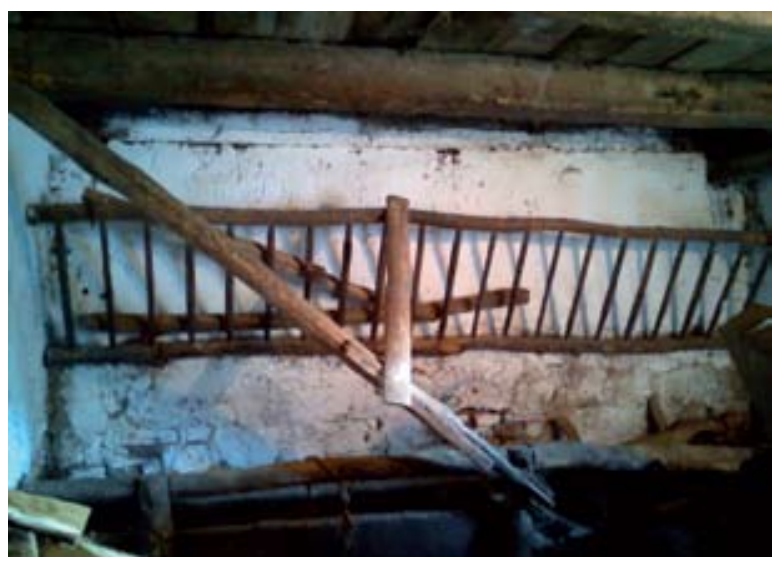

4. ábra: Etetőrács ló és marhák közti választórúddal (Kisgyalán, Kossuth utca)

Figure 4: Feeding place separated by a bar for horses and cattles (Kisgyalán, Kossuth Street)

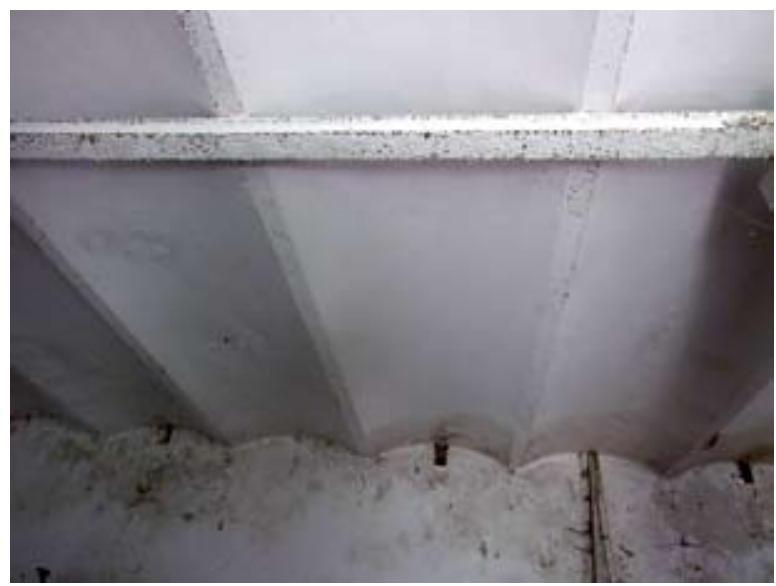

2. ábra: Mennyezetgerenda vasból (Fonó, Petőfi utca) Figure 2: Iron rafter (Fonó, Petőfi Street)

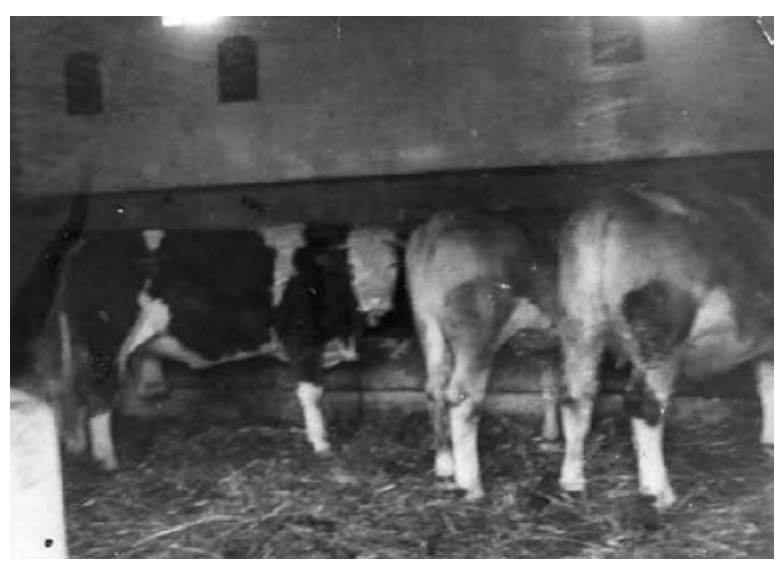

3. ábra: Tágas, szellős istálló, hosszú állásokkal Figure 3: Spacious shed with long stalls

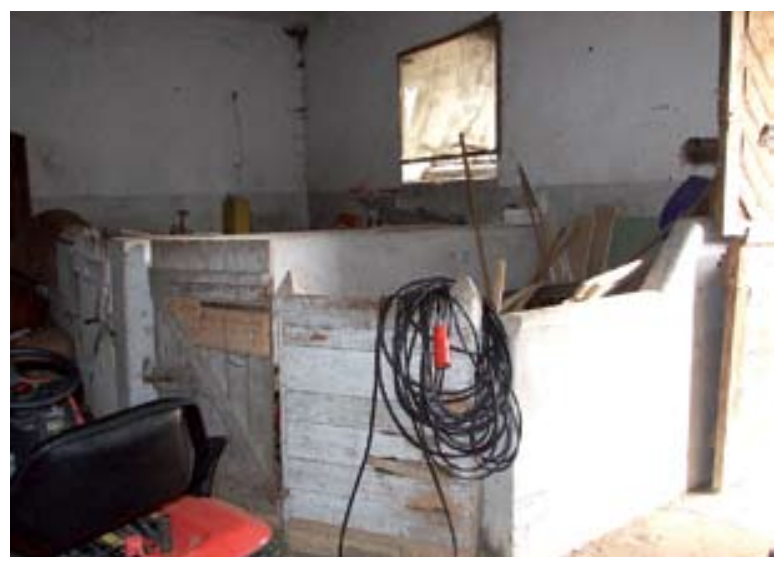

5. ábra: Borjú zárt kötetlen tartása (Fonó, Petőfi utca) Figure 5: Calf kept in a stall (Fonó Petőfi Street) 


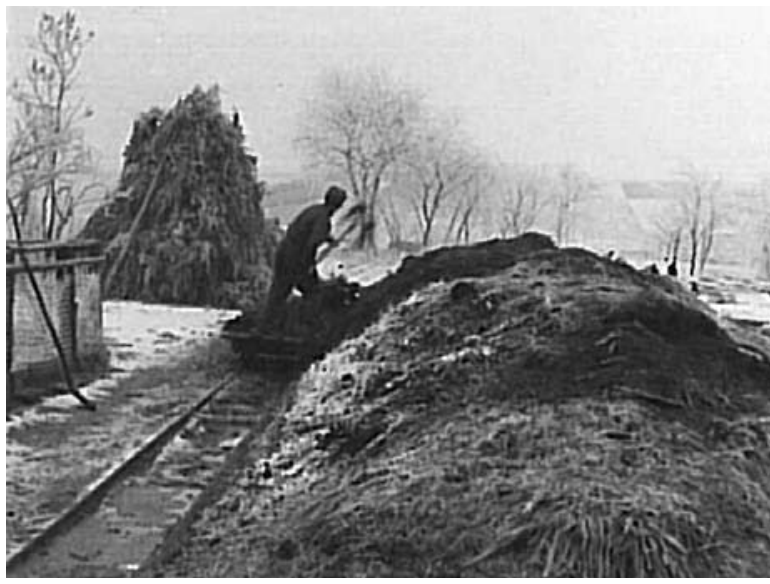

6. ábra: Pánvádlés kocsi a trágya kitolásához (Fonó, Petőfi utca)

Figure 6: Cart for pushing dung aut (Fonó, Petőfi Street)

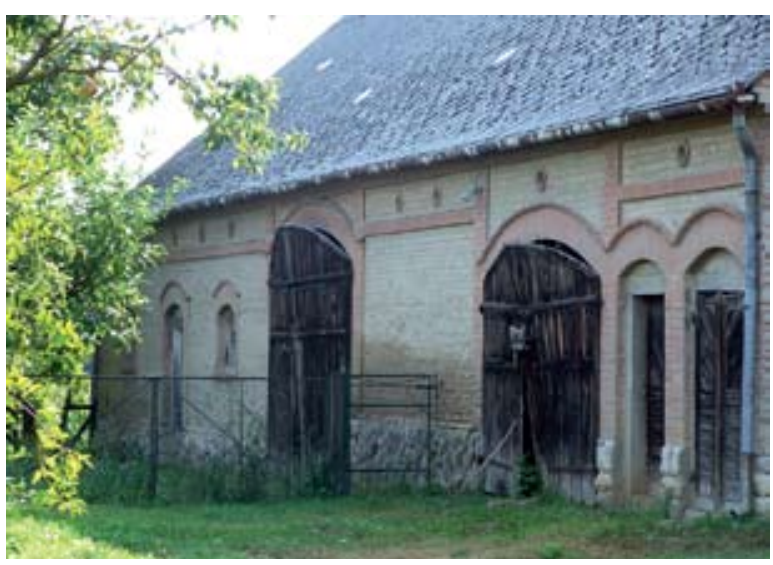

8. ábra: Az istálló az épületegyüttes végén található (Fonó, Petőfi utca)

Figure 8: Stable at the end of the block (Fonó, Petőfi Street

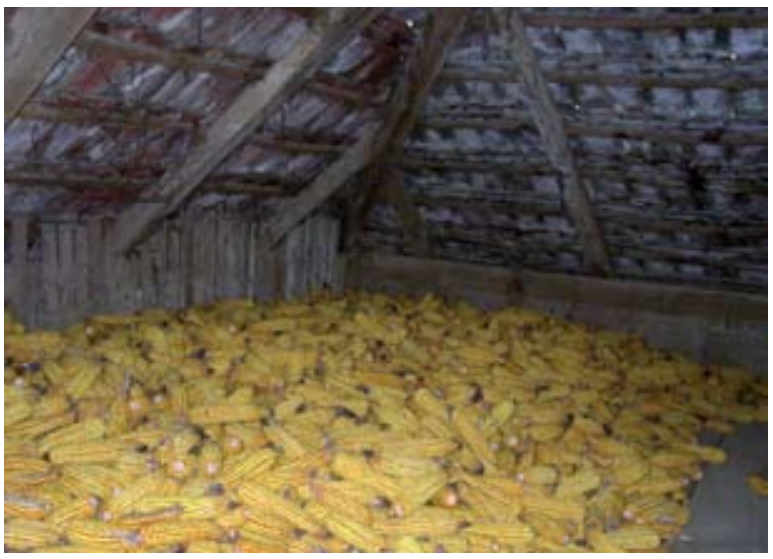

10. ábra: Kukoricatárolás garmadában (Kisgyalán, Kossuth utca)

Figure 10: Corn storing in garmada (Kisgyalán, Kossuth Street)

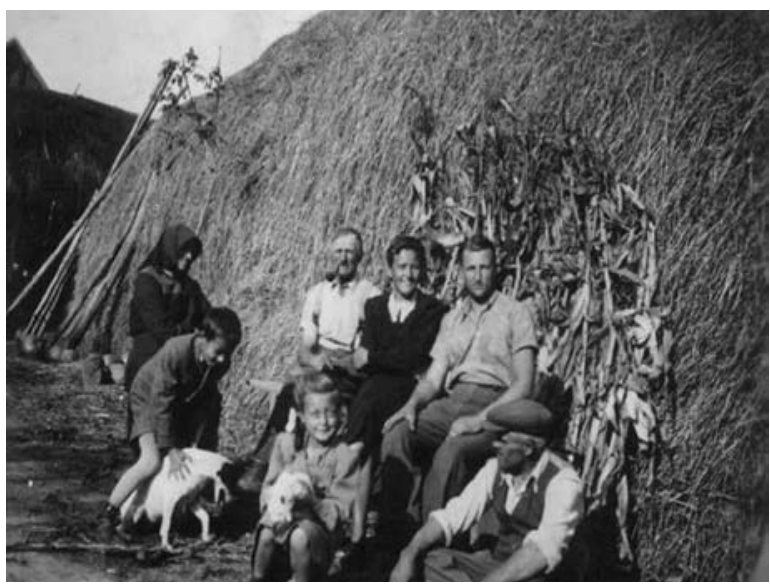

7. ábra: Kazal Kisgyalán

Figure 7: Stack Kisgyalán

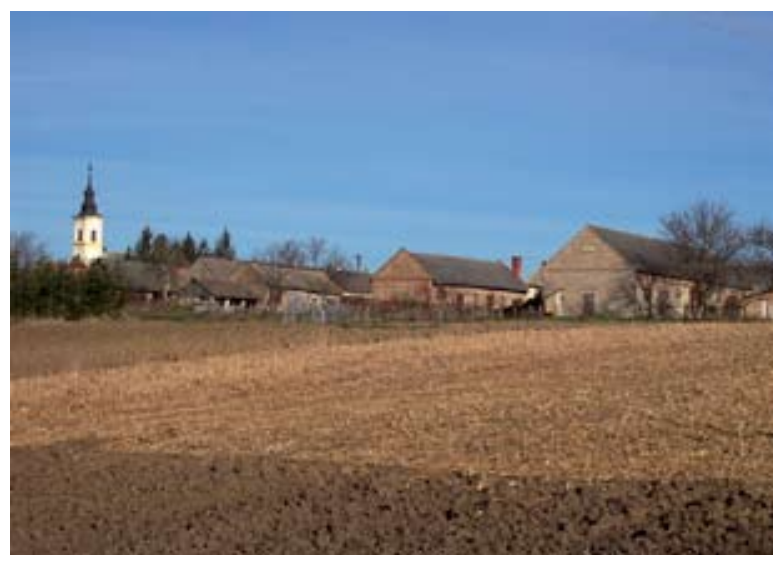

9. ábra: Fonó látképe

Figure 9: View of Fonó

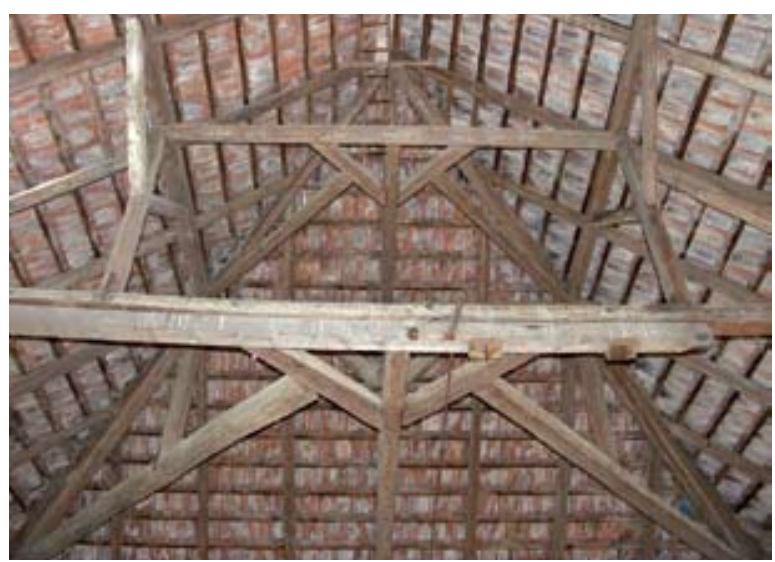

11. ábra: Ollólábas tetőszerkezet (Fonó, Petőfi utca) Figure 11: „Ollólábas” roof (Fonó, Petőfi Street) 


\section{TARTÁSTECHNOLÓGIAI ELJÁRÁSOK VÁLTOZÁSA A 20. SZÁZAD MÁSODIK FELÉBEN}

Ezért tartani kellett minden esetben az elszabadulás lehetőségétöl: „Elszabadulás esetére, kitörés ellen, nyáron, lécajtó volt kívülre rakva, sokszor féltünk, hogy ki tudják lökni a bikák."

Gondolni kellett arra is, hogy kiállításokkor, „leadáskor," (értékesítéskor) a bika könnyen kezelhető legyen, el lehessen vezetni az adott helyszínre. Ezért havonta általában egyszer, kivezették az istállóból és megjártatták az utcán. Ha mód volt rá elvitték mérlegelni, „mázsálni”, a „mázsaházba”. ${ }^{4}$ Különösképpen kellet vigyázni az 500-600 kg-os állat vezetésével. A bika szutyakjába (orrába), ilyenkor rúgós csíptető karikát helyeztek, amitől ha a kelleténél kissé élénkebb vérmérsékletü is volt az állat kezessé vált, mivel az orrát féltette, lévén érzékeny pontja. Ezért legtöbbször "férfiember" segítségét kérték az elvezetéshez, ahol több leadandó bika volt egyszerre. Az idegent azonban kevésbé fogadta el a bika, így volt, hogy háromszor is elrántotta magát. Már az első szabadulási kísérlet után felszólalt a ház asszonya, akihez szokva volt az állat: „adja ide majd én, elvezetem!" A férfiúi hiúság azonban nem engedet, így még kétszer kellet megismétlődni a szabadulási akciónak, hogy átengedje asszonyának a bikát. „Szekáták” (bosszantották) is a bika átadására kényszerült férfiút, hogy nem tudott egy bikát elvezetni. Ezekből a kis példákból is kiviláglik, hogy ekkor még mennyire nagy szerepe volt a falu egymásrautaltságának. Ha kellett bármikor, akár éjjel ment segíteni az egyik ember a másiknak. Ami aztán értelmes beszédtémát is adott a falunak.

„Úgy kell észrevenni, mit akar az állat, nem tud beszélni. Együtt kell érezni vele!” Ezt a szempontot tartották szem előtt, ezért értek el olyan szép eredményeket. Előbb hívtak állatorvost a beteg szarvasmarha, ló számára, mint orvost a beteg családtag részére. A legfőbb irányelv a gazdaság előmenetele volt. ${ }^{5}$

Betegség esetén is egyedenként eltérő volt a kezelés, ugyanarra a bajra különböző volt a gyógyír. Felfúvódás veszélye elég gyakran fennállt, ha a bendő gázok nem tudnak távozni, akár elhulláshoz is vezethetett. Ennek megelőzése végett, az egyik bika egy „véndő" (zsírtároló edény) zsírt, a másik egy hordó bort megivott mire leadásra került. Ez úgy történt, hogy a hajlamos egyedek közül, az egyik minden reggel egy marék zsírt kapott, a másik egy sörös üvegből bort a felfúvódás ellen. Ehhez kellően hozzá is szoktak, el is várták egy idő után. Ugyan így volt az a bika, ami csupán kedveskedésből egy szelet kenyeret kapott. A munkafolyamatok közül a trágyázás szintén jelentős erő, és idő igényes folyamat. A legtöbb családnál ezt úgy oldották meg, hogy kitolták a "ganyét” (trágyát) talicskán, vagy ahol kevesebb állat volt, a vállra helyezett vellával, többszöri fordulóval tették ezt meg. A legkorszerübb trágyázási mód azonban az volt, ha az istállóból keskeny vágányú vasúti sínpár vezetett ki a trágyadombhoz, amin a perem nélküli sínre illesztett, lapos rakfelületü „pánvádlis kocsi” közlekedett, amit „csak” ki kellett tolni. Ennek kitolása kevesebb erőkifejtésbe került, mint a vállon vitt vella vagy a talicska kitolása (6. ábra).

Így a "ganyédomb" (trágyadomb), is kellő méretet öltött a „szürüben”. Ez bizonyos fokmérő szerepet is betöltött, minél nagyobb volt a ganyédomb, annál kelendőbb volt az eladósorba került lány, aki feltételezhetően kellően gazdag volt. Az 1970-es években is még arra bíztatták Fonóban a háztűznézőbe menő fiút, hogy feltétlenül nézze meg a trágyadombot a lányos háznál. Volt, aki a házasságkötés után tréfálkozott is vele: „Na, jól ráfaragtam, nem volt ganyédomb!"

A trágyadomb helyét, volt ahol kibetonozták, vagy legtöbb helyen kideszkázták. Ebből a trágyát az úgynevezett „ganyéhordáskor”, juttatták ki a földekre, illetve a háztáji kertekbe. A később épült, gazdasági épületeknél, Fonóban kettőnél nem az istálló foglal középen helyet, hanem a pajta. Az istálló a hátsó udvar felöli szélen található. A trágyadomb így az istálló végében volt, így nem kellett az udvaron keresztül tolni a trágyát.

A szalma tárolása kazalba történt, amíg a szürüben masinált a cséplőgép. Később mikor már báláztak, akkor a kisbálát ahol csiga volt, ott ennek segítségével az istálló padlásra rakták fel. Szénakazlak is azokban az udvarokban sorakoztak föként, ahol nem az istállós pajták voltak jellemzőek (7. ábra).

„Ahol nem volt akkora pajta, csak ott v'ót kazal." Ugyanolyan értékmérő volt a széna és szalmakazlak mérete a „szürübe”, Kisgyalánban, mint Fonóban a trágyadombnak. Az 1980-as években is elhangzott másik falubeli fiú szájából, miután betekintett a lányos ház „szürüjébe”, hogy ezt a lányt érdemes feleségül venni, mert sok a szénakazaljuk. A „szürü” szót azért hangsúlyoztam, mert mára ennek a szónak a használata megszűnt. A rendeltetésszerű használat megszűnésével, a szóhasználat is átalakult ugyan nem egyik napról a másikra, de napjainkban már nem a „szürübe” megyünk trágyadomb és kazlak híján, csak a „hátsó udvarba” megyünk, vagy egyszerüen „hátra” megyünk. Nem értve a szóba többet, mint amit valóban gondolunk, a házhoz viszonyítva valóban „hátra” megyünk. A szürüből kiérünk a „szívásba”, (szilvásba) ahol a szilvafák állnak, már ugyan csekély számban, de ahol még zöldellnek, ott „szívás” a nevük, a gazdálkodás történetére utal ez a növényzeti gyüjtőnév.

Ahol az istálló van hátul az már valószínüleg ésszerüségi okokból épült így. Az istálló a trágyadombhoz így került a legközelebb. „Na most, hogy a Witmannék voltak az okosak azt nem tudom. Ha a kőmüves is hozta az ötletet, az igent akkor is Witmannéknak kellett kimondani." ${ }^{6} \mathrm{Ha}$ az istálló van középen, így a kisebb istálló ajtó, és mellette jobbról, balról a tégla berakással díszített ablakok, a boltíves nagy ajtók pedig az épület szélére kerültek, ily módon szimmetrikusabbnak hat az egész épületegyüttes. Kérdés, hogy a szimmetria, vagy az egyszerübb munkavégzés a fö szempont. Bár ha az istálló a gazdasági épület végén található, az a variáció épp oly mutatós, ugyanúgy magán hordozza a külcsínre való igény jeleit, csak legfeljebb kevésbé szokványos (8. ábra).

$4 \quad$ A hídmérleget hívják így amelyhez fedett épület tartozik.

5 Márkó József (1937) Kaposvár Petőfi u. 21.

$6 \quad$ Pál Elemérné 
Az istállós pajták vannak magasabban a trágyadombok lejjebb (9. ábra).

Az épületegyüttes padlásának szerepe, szintúgy kiemelkedő fontosságú volt, mint maga az épület. A 100$150 \mathrm{~m}^{2}$ területű padlásteret a kukorica tárolására használták ki Fonóban. Kisgyalánban a kisebb alapterületü istállók révén a tárolásnak erre a módjára kevésbé volt lehetőség, ezt a célt ott a górék szolgálták. Fonóban szintén ahol kisebb alapterületü gazdasági épületek készültek ott építettek górékat. Kivételt képez egy eset, amely a komplex gazdasági épületegyüttes udvarában áll, ennek sem emlékeznek építési évére, valószínüleg az istállós pajta elkészülte előtt építették.

Kisgyalánban tetszetős téglalábakon álló lécgórék találhatóak. Ezek kihasználtsága a jelen években kezd csökkenni. 2007-2008-ig a háztáji kertekben kézzel leszedett kukoricacső került a górékba, amit aztán a szinte mindenhol megtalálható zsurmolóval „kopoztak le" (kukoricacsőről a szem lenyerése). Mára csupán itt-ott található elvétve egy-egy góréban csöves kukorica. Azonban ezek a górék biztos, hogy méltó díszei maradnak az udvaroknak akkor is, ha nem eredeti céljukat szolgálják.

A helykihasználtság végett esetenként a disznóól padlásra hordták fel a kukoricát (10. ábra).

„Amelyik padlásnak nem volt falmagasítása, arra a gabonát garmadába öntötték...A padláson bizony télen sokszor belepte a hó a gabonát."7 Kisgyalánban több helyütt megfigyelhetők lécezett falmagasítások, a sertésólakon, Fonóban ez kevésbé jellemző.

A csumás kukorica útját nyomon követve Fonóban, következő volt a betakarítás menete: „A csumás kukoricát ${ }^{8}$ sar'óval levágtuk, a hosszú kocsira öntöttük. A kocsi deszkával meg volt toldva, mert könnyü volt a kukorica ezért többet lehetett rárakni. Ezt az udvaron leöntötték, este összegyütt az ismeretség fosztani. A kukorica csumája a bikák számára szolgált takarmányul. Másnap lett a padlásra fö' paku'va csigán. Ez a csiga száraz fából készült, amin, rudaló kötélen két-két kampó lóg, ebbe lehet beleakasztani a vékát és lehet le fő' eregetni amit éppen szükséges, kukoricát, bálát, hagymát. Ki az istállópadlásra, ki a ház padlására tárolta be a kukoricát, ezeken, a helyeken jól szellözött. Ennek a betárolásnak a folyamata fél napig is betartott. Két személy szükséges hozzá mindenképp, egy megtölti és ráakasztja a vékát a kampóra és felhúzza, a másik leveszi a vékát, kiönti, majd leengedi a csigán a vékát. $A$ vékát fel kellet öltöztetni, hogy a szem ne hulljon ki belöle. Nejlonnal ki kellett bélelni kívül-belül, majd rá körü' varrni a nejlont, úgy hogy a belseje kivü' lett hajtva." 9 Amíg nem volt csiga, fél zsákszám hordták fel a kukoricát a padlásra, amíg többeken át nem adták a csigás módszert egymásnak. Ezeket, a csigákat Böröcz József készítette Büssüben, onnan terjedt el Fonóban is. A két község távolsága $8 \mathrm{~km}$. A köztük

$7 \quad$ Nagy Gy. 1963: 101.

8 Kisgyalánban nem csumásan szedték a kukoricát, viszont Fonóban, Göllében igen, itt is tapasztalható a kis 3-4 km-es távolságok ellenére a szokások közötti különbség.

9 Pál Elemérné fekvő Kisgyalánban nem terjedt el a csiga használata, ${ }^{10}$ bár Böröcz Józsefet ott is ismerték. Ennek oka szintén a két község eltérő góré számával magyarázható. A górékba való csöves kukorica betermeléséhez nem alkalmaztak csigát, oda úgy „burogatták”(borították) be a kukoricát.

„Csigán, látjátok csak könnyebb, mint zsákban. Az egyik szomszéd kölcsönadta, leódtta (leoldotta) a másiknak, míg kipróbálta, hogy rá szánja-e magát a vételre. Mert hát mindennapi dó'got (dolgot), nem lehet mástól kérni. Mindenki beszerezte, amire szüksége volt, nem jellemző a kölcsönkérés." ${ }^{11}$ Az 1960-as évek után, már csak a zárt kertekböl került betakarításra csöves kukorica, a szükséglet többi részéhez szemes formába jutottak hozzá a gazdák. Ekkortól már gépjármüvek szállították a szemet, MTZ traktorok, IFA-k. Amik sajnos több gazdasági épületen is nyomot hagytak, "háromnak is bánta a sarka," 12 azáltal, hogy az IFA neki tolatott az épületnek. Bár ez nem feltétlen írandó a soför számlájára, Ő a hely szükös voltáról igazán nem tehetett, ha megfordulni nem lehetett, akkor tolatni kellett. Általában egy $10 \times 10$-es ponyvára billentette le a kukoricát, a ponyva duplán került leterítésre, a kiszakadás veszélye miatt. Valamint így könnyebb volt mozgatni rajta a szemet is. Amikor már fogyott le róla a szem, lehetett összehajtogatni, hengergetni. A vödörrel meréskor óvatosan kellett a fém vödör peremét meríteni, nehogy kiszakadjon a ponyva. Ponyvát úgy is készítettek, hogy elszakadozott nejlonzsákokat varrtak össze. A szomszédok, rokonok, ismerösök, ha látták, hogy valaki udvarába beáll a termelőszövetkezet IFA-ja rögtön indultak vödrökkel a szemet bemerni. Az egymás segítése a gyorsaság miatt is fontos volt, hogy esetleges zápor esetén, „oda ne ázzon” az udvarra a szem. „A szemet is ésszerübb volt a padláson tárolni ott jobban szellözött, mint esetlegesen lent építeni valamilyen tároló helységet, ott ugyanis könnyebben bepenyhedt (benedvesedett) a szem, összepenészesedett, sőt a patkányok is bepiszkitották. Az egerek is tudtak pocskosságot (pocsékolást) csinálni." 13

Árpából általában kevesebbet vásároltak a gazdák, ekkor a „szárogatás” ${ }^{14}$ után a magtárból merték fel zsákokba a szemet. Mennyivel szebben hangzik így ez a szó, hogy szárogató, mint a szárító! Kisgyalánba áll még a régi 1970-es években épült szárító, amit még mindenki szárogatónak hív, az újat, a 2000 évekbelit szárító névvel illetjük. Egy szóból tudja mindenki, hogy melyikre gondolunk, nem kell magyarázkodni, hogy új vagy régi. Ugyanakkor a gyakorító képzős szárogató szóból kisejlik, hogy teljesítőképessége kisebb a szárítóénál.

Azsákokról is érdemes pár szót szólni. Magtárosként volt rá módom rácsodálkozni, igen sok szép példányra. Ezek a szépen simára szőtt, szájukon rávarrt madzaggal, név, utca, házszám, díszítés rányomtatásával ellátott zsákok főként Fonóban voltak jellemzőek.

\footnotetext{
10 Kisgyalánban Göndöcs Béláné portáján található csiga.

11 Pál Elemérné

12 Repedések keletkeztek az épületek falain.

13 Pál Elemérné

14 A kívánt szárazanyag tartalom elérése.
} 
„Most már a rosseb eszi, fönn a palláson a szüttes (szőttes) zsákokat.” Ez a szó szerint idézett mondat sokat elárul, egyrészt a rosseb utal somogyi mivoltunkra, másrészt kifejezi azt az elkeseredést, miszerint az által, hogy eszi, nem a rendeltetésük szerint vannak használva. A későbbiek folyamán a termelöszövetkezet évei alatt, legtöbben állatjelölő krétával a monogramjukat írták rá zsákjaikra. Igényesebb módja volt a jelölésnek, mikor tintaceruzával folyóírással írták a zsákra a nevet. Ezeket a szőtesszsákokat követte az úgynevezett „csolány”, vagy juta zsák. Ebből is illett 20-40 db-ot tartani egy háztartásban. A táp, koncentrátum, az 1980-as években föként nejlon zsákban került forgalmazásra. A fehér, fényes műanyag zsákokban vetőmagot értékesítettek, ezért sokáig rajtuk maradt, hogy vetőmagos zsák, mikor már nem is azt tároltak bennük. Ezek igen kelendőek voltak, könnyebben kezelhetőek, mint a csalánzsákok, kisebb súlyúak, könnyebb eltávolítani belőlük a port, ha kirágja az egér pótolható, kevesebb helyet foglal. Az úgynevezett vetőmagos zsákot foltozni sem kellett. ${ }^{15}$ Ezekhez a zsákokhoz nem is olyan könnyü volt hozzájutni, így hát a termelőszövetkezetből igyekezett mindenki szükségletének megfelelően, ingyen bérmentve beszerezni. ${ }^{16}$

Fonóban a hatalmas pajta a szükséges széna menynyiséget maximális mértékben befogadta. Így a tárolási veszteséget minimálisra lehetett csökkenteni. A kazal beázik, ha le van takarva, akkor is, a hatalmas belmagasságú pajták esetén ez nem történt meg. Az ollólábas tetőszerkezetek, ma is ámulatba ejtik az embert (11. ábra).

Többen is, minden esetben asszonyok, ugyanazon szavakkal élve, így emlékeztek vissza: „Sokszor a vellámmal kotorásztam a tetőt. A betermelés úgy történt, hogy a pajta ajtón behajtott a kocsi, a lovak pedig a pajta ajtóval szembe lévő kisebb méretü ajtón kimentek a szomszéd udvarába. Tehát a pajta közepén állt a kocsi, a szomszédban keresztbe álltak a lovak."17 (12. - 13. ábra).

Miután a széna lekerült a kocsiról, a ló nem a szomszéd felöl kanyarodott ki, - bár erre is volt példa - hanem „kicurikkoltatta” (kihátráltatta) a lovakat a gazda saját udvarába. Más megfogalmazás szerint „kisegge'tek” a lovak a pajta kapun. A pajta ajtónak kellően szélesnek és magasnak kellett lennie, hogy a megrakott szekér beférjen rajta. A szomszédba nyíló kisebb ajtókra pedig Kisgyalánban nem ismerek példát. Fonóban az ésszerüség hívta életre őket, na meg a megengedő rokoni szálak. „Aki nem volt haragba a szomszédjával megengedte. Minálunk nem volt differencia."18

15 A csalánzsák ha kilyukadt akkor, esős napokon a termelőszövetkezetben zsák foltozás volt a napi munka.

16 Kis értéket képviselt darabonként, így hát senki nem tekintette lopásnak, egyszerüen hazavinni a közösböl. Ma már ezeknek a zsákoknak sincs meg a kellö becsületük, nem kellenek senkinek. Ahogy esik, úgy puffan, ha a feneke esik felfelé senki sem fordítja meg, senki nem húzza ki óvatosan a cérnaszálat belölük, mondván jó lesz paprikát füzni. Hanem egyszerü mozdulattal, késse felszakítja a zsák fenekét, végül is, ki tud folyni a táp a zsák fenekén is! Egy idős parasztembernek nem jutna eszébe soha így megbontani a zsákot.

17 Szántó Imréné (Szabó Margit 1929) Fonó Petőfi u. 40.

18 Pál Elemérné
A gyűjtés során ezekkel a szomszédba nyíló ajtókkal kapcsolatban furcsálltam, hogy milyen szemet szúró egyszerü dolgokról, nem tudnak már a ma negyvenes éveikben járó lakosok sem, hogy fog ezeknek az ismerete pár évtizeden belül eltünni! Ha a gyakorlatban már nem alkalmaznak valamely módszert, az egy emberöltő múltán a feledés homályába merül. Például, ha egy tehetős új tulajdonos vesz meg egy ingatlant, biztos, hogy a pajtából a szomszédba néző ajtót „berakatja," (befalaztatja) téglával. Volt nincs, és miért volt, ki tudja már? A boltíves hatalmas pajtaajtók, több helyen felújították. A német tulajdonos megpróbálta eredeti állapota szerint visszaállítani, boltíves maradt az új faajtó is. A magyar tulajdonosok, már költségtakarékossági okokból, szögletes fémajtókat készítettek.

Az 1970-es évektől kezdve traktor hozta a szénát. A gazdák tudták, hogy melyik traktoros mennyire segítőkész, vagy épp mennyire fáradt. Fontos megoldandó kérdés volt, leszáll-e a traktorról és segít-e feldobálni a szénát. A széna pajtába való elrakása három személyes feladat, egy ledobta a kocsiról, egy föladta egy nagyon hosszú nyelü vellával, egy átvette és elrakta a szédületes magasságba.

Azonban a nagy pajtát nélkülöző udvarokban, a kazal rakása sem lebecsülendő munka. A kazlak sarkainak kirakása is megkívánta a kellő szakértelmet, ami szintén generációkon át adódott tovább. A kombájnok megjelenése után a kisbálák terjedtek el először, ezek ma is népszerüek könnyen kezelhetö kis súlyuk miatt. Fedett helyre szépen be lehetett sorakozatni őket, Fonóban ez is több helyen csigán került fel az istállópadlásra.

Amíg, az 1980-as évekig telt házzal működtek az istállók, addig vontató (traktor pótkocsival) szállította be az udvarra a kisbálát. Ezt darabra lehetett vásárolni, a pótkocsi legtöbbször maximálisan meg volt rakva. Később az 1990-es évek után, csak a hídra ledobálták a lecsökkent igény szerinti kisbálát, és a gazda maga hordta be a szalmát az udvarba.

A nagy bálákat kevésbé szerette a gazdaközönség, nehezen kezelhető, mozdítható, fedett helyre kevésbé van mód betermelni. Így kint beázik bizonyos százaléka, veszendőbe megy.

Az 1940-as években Fonóban is építettek betonsilót. 25-40 $\mathrm{m}^{3}$ szecskázott zöldtakarmányt savanyítottak benne, ez a siló 2010-es használaton kívüli, de megbecsült állapotban ma is megtalálható. Amíg személyes kötődés van egy tárgyhoz, addig biztos, hogy megörizzük az eredeti állapotát, a siló jelenleg is ugyanazon család tulajdona. Az épületekkel kapcsolatosan szintén a megóvás a jellemző.

A hagyományok őrzése apróbb dolgokban is megnyilvánul. Még 2013-ben is színes virágokkal telt virágos pad található Kisgyalánban, igaz, már csak két helyen találkozhatunk vele (14. ábra). Az ésszerüség még itt is megnyilvánul, magas lábakon áll, ahogy a neve is mutatja. A cserepeket védő keret pedig díszit is, és ráadásul eredeti funkcióját tölti be. 

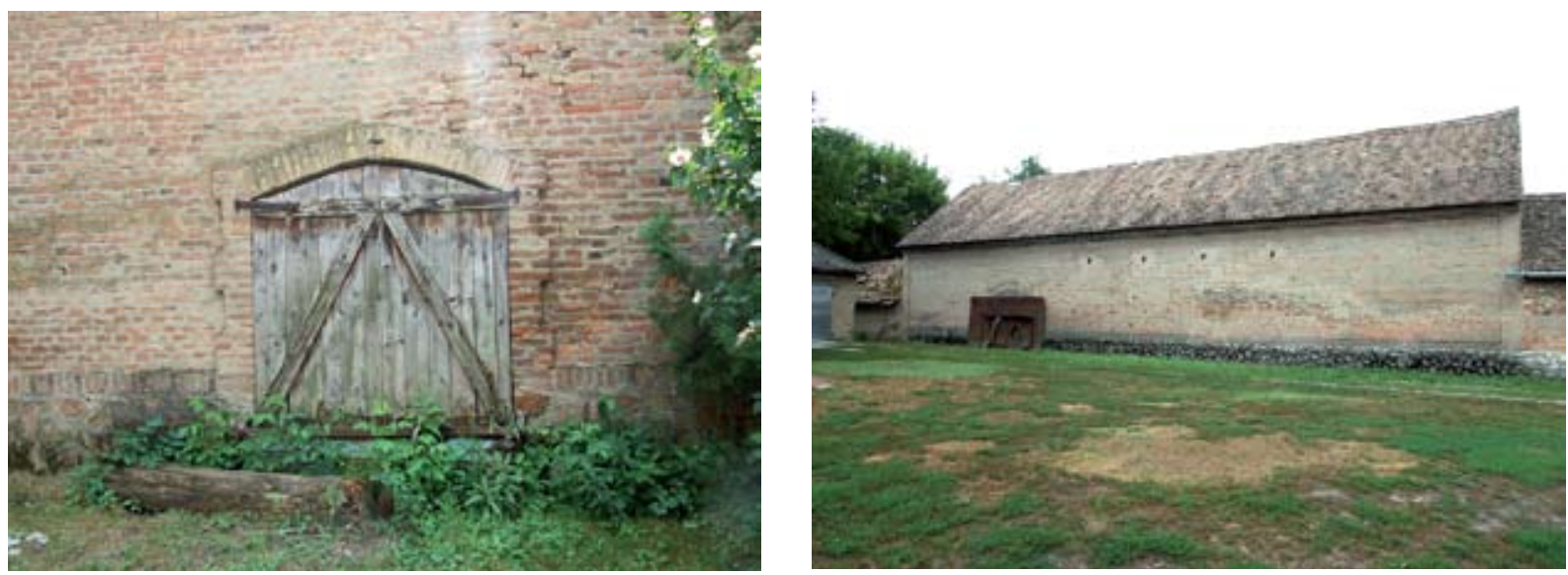

12. - 13. ábra: Hátsó pajta kijárat (Fonó, Petőfi utca)

Figure 12-13: Back exit of a shed (Fonó, Petöfi Street)

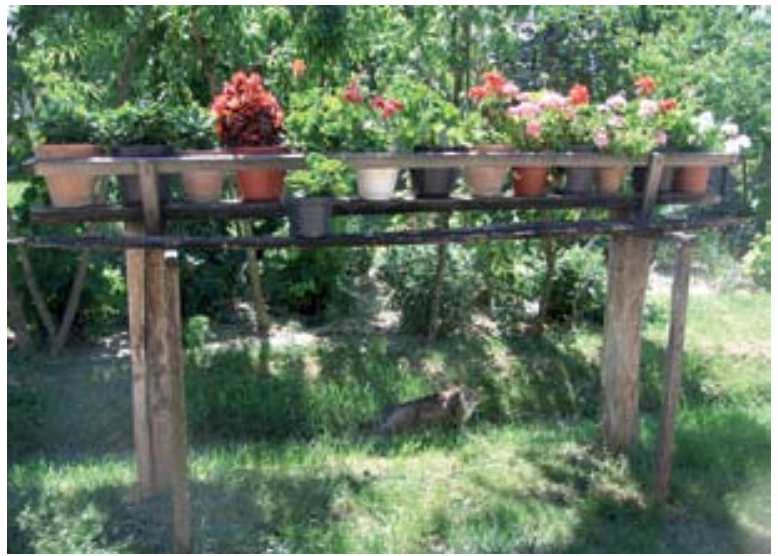

14. ábra: . Virágospad (Kisgyalán, Árpád utca) Figure 14: Bench with flower patterns (Kisgyalán, Árpád Street)

„Muskátli díszlett az ablakban, vagy a virágos padon. A ház előtt két cölöpre deszkát szegeztek, erre tették a virágot, hogy a baromfi ne bántsa." ${ }^{19}$ Hasonlóképp hangulatosabbá teszi Kisgyalánban az egyik udvarban található gazdagon díszített kút is az udvarképet (15. ábra).

Jelenleg tényleges gazdasági funkcióját, a tyúkól, a pince, egyre kevesebb helyen a füstölő tölti be. A leghíresebb szarvasmarha-tenyésztő község istállóiban itt-ott esetenként nyulak találhatóak. A fénykorban 1910-1950 között a tenyészbika, üszőnevelés volt a cél Fonóban. Majd ezt követően 1950-1980 között a

19 Knézy J. 1974: 56.

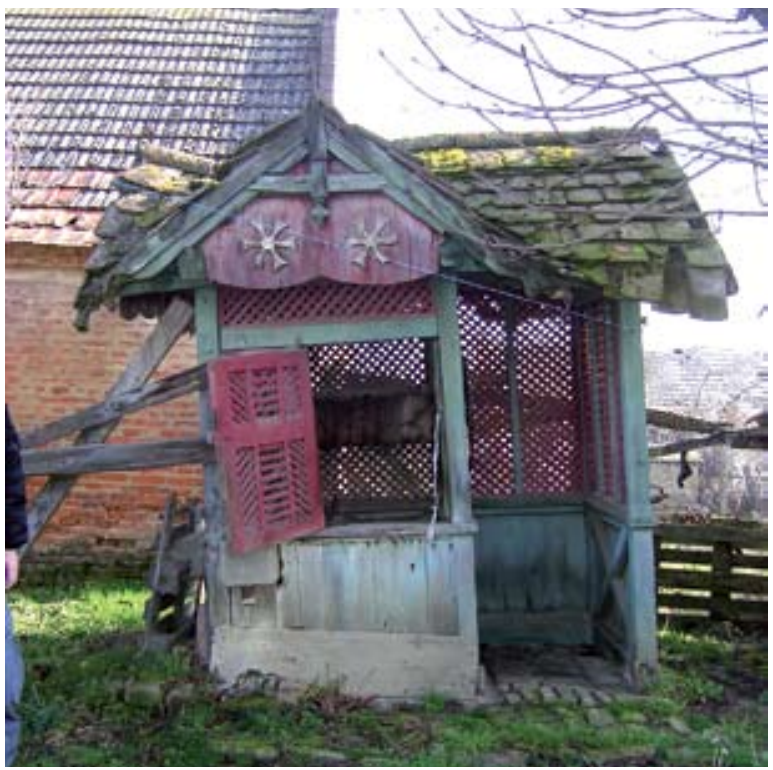

15. ábra: Gazdagon faragott kút (Kisgyalán, Árpád utca)

Figure 15: Ornamental well (Kisgyalán, Árpád Street)

hízóbika nevelés jellemezte Fonót és Kisgyalánt egyaránt. Az 1980-as években a Kisgyaláni Petőfi Termelőszövetkezet, Fonóban és Kisgyalánban egyaránt hízóbika kihelyezés lehetőségét nyújtotta tagjai számára. A gazdák ezt maximálisan igyekeztek kihasználni, minél több bikát szerettek volna többen tartani. Ezért Kisgyalánban, ahol kevesebb állatot befogadó, kisebb alapterületü istállókat építettek, a hely szüke miatt az állatok életritmusát figyelembe véve, olyan építmény is készült, amelyben tavasztól őszig tartózkodhattak a bikák. A borjú utónevelést követően kerültek a termelőszövetkezetből kihelyezésre a növendék bikák ebbe a szükség építménybe, amiből a fagyok beállta előtt „leadásra,”értékesítésre kerültek. 


\section{FONÓ ÉS KISGYALÁN KÖZSÉGEK GAZDASÁGI ÉPÜLETEIBEN ALKALMAZOTT TARTÁSTECHNOLÓGIAI ELJÁRÁSOK VÁLTOZÁSA A 20. SZÁZAD MÁSODIK FELÉBEN}

\section{Szükség építmények}

„Megfigyelhető az is, hogy a régi technikák és megoldások, föként gazdasági szükséghelyzetben újra megelevenedhetnek a gazdasági vagy ideiglenes építményeken." ${ }^{20}$ Ideiglenes voltából adódóan a "gunyesz" (nyári szállás) titulust kapta a gazdájától, ezzel is érzékeltetve jövőjét előre vetítve múlandóságát, amely az1980-as évektől a 2000-es évek elejéig állt, akkor lett „felborítva.” „Házilag kifaragott fadúcok képezték a gúnyesz vázát, az oszlopokat korlátfa kötötte öszsze. A gúnyesz oldala csutaszárral (kukoricaszárral) volt betámogatva. A csutaszár össze volt kötve, a tüje (töve) nézett felfelé.” ${ }^{21}$ A rögzítéshez újra felhasznált, szükséges szögek, kapcsok, már akkor erősen rozsdásak, az építmény színvonalához hasonlatosak voltak. Egy idős parasztember ma sem hajít ki semmit, aminek úgy érzi, hogy valaha hasznát veheti, ma is bádog dobozban őrizgeti a rissz-rossz szögeket, vasdarabokat. A beállított mobil jászlak előtt, valamint a bikák ágyéktájékától hátrafelé ki volt téglázva az építmény. Az előbbi a szilárdítás végett, hogy a bikák ne tudják kidönteni a „falat,” az utóbbi pedig, hogy „ne merüljön el a sömlékben (trágyalében) a bika," ugyanis így könnyebb trágyázni alóla. „A tetejét sürü faléceken szómabála (szalmabála) borította, hogy ne ázzon be erre kerültek a póznák, szalmacsutakkal kötve a fa egyik felül, és a másik felül is, így a szél sem tudta lefújni a tetőt. A bikák őszre kelve elmentek belöle." Ennek az építménynek már csak a kertben jutott hely, így az ivóvizet slaggal kellett kivezetni a kertbe. A gunyesz tájolása dél-nyugati volt.

A szükség építmények kategóriájába tartozott a „pelyvás kóter” (fa és növényi szárakból készült építmény), ami lakhelyül is szolgált, amíg az új ház el nem készült. A szíves adat közlő visszaemlékezése szerint, a legnagyobb örömül az az apróság szolgált: „Mikor végre kiszabadultunk a pelyvás kóterből és az új házba érkező vendég kopogni tudott az ajtón és ezt a kopogtatást lehetett hallani!"

„Az építmény falát négy levert oszlop köré állogatott csutaszár alkotta, a teteje igyenes (egyenes) volt, a sürü léceken csuta, ezen pedig szóma (szalma), 1962ben míg az új ház el nem készült itt laktunk Pünkösdtöl Nagyasszonyig." 22 A szükségépület kihasználtságát, itt is az időjárási tényezőktől tették függővé. A polyvás kóter további funkciójára utal a jelennel párhuzamot vonva az alábbi megjegyzés: „Régen volt a polyvás kóter, most meg van a discó!"

\section{Az istállók funkció váltása}

Az 1990-es évekre már a gazdák „kezdtek kiöregedni," gyerekeik tovább tanultak, városba telepedtek le. Az 1990-es években áttértek, fokozott mértékben a hízósertés nevelésre, mindkét községben. A sertések

20 Kottmayer, T. 2003: 7

21 Bóna Lászlóné (Széles Rózsa 1930) Kisgyalán Árpád u. 33. szíves közlése.

22 Bóna Lászlóné ellátása nem vesz kevesebb időt, energia ráfordítást igénybe, mint a szarvasmarháké. Azonban egy idősödő ember a bikával már nehezebben boldogul, könynyebben kezelhetőek a sertések. Az 1990-es években a Kisgyaláni Petőfi Szolgáltató Szövetkezet, már nem bika, hanem sertés kihelyezéssel foglalkozott. A sertések szintén bértartásba kerültek a gazdákhoz, ekkor a tápot is biztosította a szövetkezet az állatok számára, a gazdáknak a férőhelyet és bérmunkát kellett biztosítani. A gazdák ekkor is alkalmazkodtak a mindenkori igényekhez, istállóikat mindkét községben számos esetben átalakították a sertés tartás technológiai követelményeinek, „fakkokat” (válaszfalakat) alakítottak ki az istállón belül. A szükség helyzet, az épületek funkció váltását is kikényszeríti adott esetben. Majd az 1990-es évek végére a sertés leadás is lassacskán megszünt, a saját vágásra hizlalt sertésen kívül értékesítésre nem tartottak a gazdák állatot. Oka: a korosodó idős emberek, már a leadások, szállítások alkalmával, az állatfelhajtóra egyre kevésbé tudták felterelni a disznókat. A szomszédból sincs lehetőség kit áthívni segíteni, a legtöbb fiatal a közeli Kaposváron dolgozik. Így hát szép lassacskán mindenki abbahagyta az értékesítésre történő sertéshizlalást is. Itt-ott nyulakkal is próbáltak foglalkozni, „még járta a falut” a nyúlátvevő kocsi. Végül a központilag szervezett nyúlszállítás is megszünt. Nyulakkal is már csak saját szükséglet céljára foglalkoznak a fonóiak és a gyalániak úgyszintén, amik főként az istállókban kerülnek elhelyezésre. Az épület rendeltetésszerü használata idején, a nyúlketrecek természetesen az istállón kívül kerültek elhelyezésre.

A disznóólak üressé válása után, tyúkok kerültek a sertések helyére, több helyen megtévesztő célzattal, az úgynevezett megélhetési bủnözés ellen. Mondván, ha a tolvaj üresen találja a tyúkólat, amit már több helyen, többször kifosztott, akkor nem keres tovább. Ez a módszer több helyütt be is vált.

Mindkét községben, számos helyen átalakították a lakóépület részévé az istállót. lly módon, nyomon követhető a gazdasági épületek sorsának alakulása, funkció váltása.

\section{Az istállóban alvásra való visszaemlékezés}

A megkérdezettek mindegyike ismerte az istállóban alvás szokását Kisgyalánban, Fonóban egyaránt, az 1960-as évek után készült istállókban azonban már nem aludtak.

Miután a külterjes állattenyésztés átalakult istállózó állattenyésztéssé, ez adta a lehetőséget, hogy az állatok felügyeletét az istállóban alvással oldják meg.

Istállóban alvás kérdésére adott válaszok teljes mértékben eltértek aszerint, hogy a szíves adatközlővel személyes ismeretségünk volt-e vagy nem. Ahol személyes ismeretségünk volt, ott még anekdotákat is meséltek az adott témával kapcsolatosan. Fonóban még azt is megmutatták, hol volt az ágy az istállóban. Kisgyalánban meg is lehetett örökíteni a múltból ott felejtett nyugvóhelyet, és vele kapcsolatban a falu egész népe számára ismert történetek is 
elhangzottak. Számos tréfás anekdota szól az istállóban alvással kapcsolatban. Például Kisgyalánban az ott alvó legényt, miközben aludt, hogy vitték ki az udvarra ágyastul, a csínytevésre hajlamos barátai. Vagy másik alkalommal, egy lavór vizet tettek és takarták le az ágyon lévő kifeküdt lyukba, a pajtások. Fonóban pedig, amikor nászéjszakára került a sor, az istállóban lévő ágy lábára kis csengettyűket kötött az ifjúság, utána pedig kint fülelt a szürüben (gazdasági udvarban). Egy másik eset az istállóajtó további lehetséges funkcióját szemlélteti, Szántó József (1893-1969) példájával. „A faluban „csak” Nagyszántónak hívták utalva magasságára ezzel, de tettrekészségével is kiemelkedett az átlagból, „szörszöm” ember volt, vagyis „nagydógos”, ezért kiérdemelte a nagy jelzőt. Ezekben a szavakban bent van a többre, a jobbra való törekvés, az előbbre jutási vágy, de tett is érte. Azért, hogy reggel el ne aludjék, ágyba sem feküdt az istállóajtón két karjára dőlve szunyókált. (Ezek az ajtók két vagy három részesek voltak, középmagasságban keresztben elválasztva.) Ilyen kényelmetlen alvást magára eröltetve nem csoda, hogy hajnalok hajnalán kelt és ment a mezőre, amikor még alig pirkadt."23

Az 1950-es évek vége felé már változott a szemlélet az életkörülményekkel együtt, az idős nagyapát, családtagokat be akarták költöztetni a szobába az istállóból, de nehezen viselték a váltást, visszakívánkoztak az istállóba, két szíves adatközlés szerint is.

Fonóban viszont nem volt a 80 éven felüliek között, akik ne említették volna meg: „Színdarabot mindig az éppen újonnan felépült istállóban játszottunk. Így a sok nép aki elment megnézni a színdarabot ledöngölte a földet."

„A gazdag ember házban nem halt meg.” „Nagyobb rangot kapott, mint egy ház!" Szintén többször elhangzott visszaemlékezések voltak Fonóban.

Mosdóson az Idősek Otthonában, személyes ismeretség nem volt. Az 1920-as 30-as években, a környező falvakban születettek számára, (Juta, Sántos, Kapospula, Attala) feltett kérdés, az ezredforduló

23 Lanszkiné Sz. G. 2007: 235-224 után majd egy évtizeddel az istállóban alvásról, tagadó választ kapott. „Újpároknak oda ki kellett menni aludni, nem is hallottunk róla?!" A válasz a csoportos felháborodás hangján, egyértelműen nem volt az ott alvás kérdésére, valószínűleg szégyellhettek igennel válaszolni egy idegennek. Mondván „ez olyan régen lehetett, hogy már mi ilyenre nem emlékszünk.” Azért lassan csak megindult a beszélgetés. „Sántoson színdarabot játszottak benne az elöbbi pó'gár világban, de nem aludtak benne.” "Belvilága nagyobb volt az istállónak, mint a lakásnak.” „Kis parasztház, az istálló akkora, mint a hodály.” "Attalában is rangosabbak voltak az istállók, mint a házak.” "Az istálló nagyobb érték volt, mint a lakóház." ${ }^{24}$ - hangzottak el a visszaemlékezések az istálló méretére, minőségére vonatkozóan. Ebben mindenki egyetértett, de az istállóban alvásra valahogy senki sem akart emlékezni. Lehetséges, hogy ha az első válasz nem tagadó lett volna, akkor igenlő válaszok is születtek volna.

A mai életszínvonallal összehasonlítva, a múlt század 50-es éveiig Göllében, Kisgyalánban, Fonóban, egyértelműen természetes tényként került szóba az istállóban alvás.

\section{Következtetések}

„Egyértelmüen kiderül, hogy ez az életforma elmúlt. $S$ ha valaki mégis visszatérne hozzá, akkor sem tudja a hajdani faluközösség nélkül megélni, mert a paraszti életforma szigorúan igazodott a közösségi szabályokhoz, a hagyományhoz, és ez a kisközösségi értékrend szintén darabjaira hullott szét. A települési közösség nem csak szabályozott, hanem együtt is müködött. Marad a megőrzés." 25 Nem kell elszabadult bika miatt az utcáról behívni senkit. Nem kell kukoricát fosztani, szénát rakni, „lesni a gépet” hozza-e a szemet. A fokozott egymásra figyelés megszűnt. Reggel a fiatal munkaképes emberek többsége fölszáll a buszra, este pedig le, ez Kisgyalánra, Fonóra egyaránt igaz.

\footnotetext{
24 Vajda Gyuláné 1929 Volt sántosi lakos. Kiss Pálné 1928 Volt bőszénfai lakos szíves közlése.

25 Kottmayer T. 2007: 18.
}

\section{Irodalom}

KIRÁLY I. Sz. 2006: Mezőgazdasági termelőszövetkezetek Somogyban (1948-1989). Kaposvár

KNÉZY J. 1974: Települési változások Belső-Somogyban a reformkor végétöl a 20. század elejéig. - Etnográfia, LXXXV: 48-60. Budapest.

KottMAYeR T. 2003: Népi építészet, népi építkezés. Egyetemi jegyzet. Széchenyi István Egyetem, Győr.
LANSZKINÉ Sz. G. 2007: Kisgyalán története és néprajza. Kisgyalán Községi Önkormányzat, Kaposvár.

LANSZKINÉ ÉS LANSZKI 2014: Fonó és Kisgyalán községek népi építészete, az istállók rendeltetésének változása

NAGY Gy. 1963: A gabona szemtermésének tárolása Orosházán. - Etnográfia, LXXIV: 84-105. Budapest. 